\title{
ARTIKELEN
}

\section{Advocaten in Europa: vertegenwoordiging op het hoogste niveau?*}

\author{
Jos Hoevenaars
}

\section{Inleiding}

Recent verscheen in het tijdschrift Asiel en Migrantenrecht (A\&MR) een artikel waarin vier migratierechtadvocaten werd gevraagd naar hun ervaring met pleiten voor het Hof van Justitie van de Europese Unie (hierna: het Hof). ${ }^{1}$ De treffende ondertitel van het artikel was 'Alles is er helemaal anders'. De vier geïnterviewde advocaten doen uit de doeken hoe ze de verwijzing van een van hun zaken naar het Hof door middel van een prejudiciële verwijzing hebben ervaren en tegen welke uitdagingen ze daarbij aanliepen. Het artikel heeft als doel inzicht te geven in de gang van zaken bij een dergelijke procedure voor mogelijk toekomstige professionals die naar het Hof moeten. Voor een breder publiek biedt het aanleiding voor een nadere bestudering van de in academische literatuur veelal onderbelichte praktijk van deze bijzondere procedure in het Europese rechtssysteem. In het onderhavige artikel wordt aan de hand van empirisch materiaal verder op deze praktijk ingegaan, waarbij twee onderzoeksterreinen bij elkaar worden gebracht: enerzijds het vraagstuk van het belang van vertegenwoordiging van justitiabelen in de rechtszaal en anderzijds de Europese prejudiciële verwijzingsprocedure.

De vraag die in dit artikel centraal staat, is met welke uitdagingen advocaten ${ }^{2}$ worden geconfronteerd wanneer een zaak waarbij individuele burgers zijn betrokken wordt doorverwezen naar het Hof van Justitie, hoe zij hiermee omgaan en wat we hieruit kunnen concluderen over de effectiviteit van juridische vertegenwoordiging bij prejudiciële procedures. Om een antwoord te vinden op deze vraag wordt gebruikgemaakt van inzichten uit interviews met advocaten die ervaring hebben met een of meerdere verwijzingen naar het Hof in Luxemburg.

De interviews die in dit artikel worden gebruikt, maken deel uit van een breder onderzoek naar de prejudiciële procedure waarvan de resultaten elders zijn gepubliceerd. ${ }^{3}$ Voor dit onderzoek werden partijen (individuen, advocaten, academici, vertegenwoordigers van ngo's en vakbonden) geïnterviewd die betrokken waren bij een zaak die was verwezen naar het Hof. De zaken die voor dit onder-

* $\quad$ De auteur dankt de redactie van Recht der Werkelijkheid en twee anonieme reviewers voor hun nauwgezette lezing van een eerdere versie van dit artikel en hun suggesties ter verbetering.

1 Geertsema \& Hesselink 2019.

2 In dit artikel wordt gebruikgemaakt van de terminologie 'juridisch professional' en 'advocaat' om zowel advocaten als andere vertegenwoordigers, zoals belastingadviseurs, aan te duiden.

3 Zie Hoevenaars 2018 . 
zoek werden geselecteerd, waren rechtszaken waarbij ten minste één individuele partij betrokken was. Bedrijven en instellingen werden dus buiten beschouwing gelaten.

Binnen het kader van dit onderzoek interviewde ik 28 advocaten die betrokken waren bij een rechtszaak die in de periode tussen 2006 en 2012 vanuit Nederland naar het Hof werd verwezen over hun ervaringen. In de interviews werd respondenten gevraagd naar het verloop van de zaak en naar hun ervaringen tijdens de procedure. In het bijzonder werd gevraagd naar hun ervaringen met de beslissing tot verwijzing door de nationale rechter, met het voorbereiden van de zaak in zowel de schriftelijke als de mondelinge fase van de prejudiciële procedure, met de gang van zaken tijdens de hoorzitting en naar het verloop van de zaak na terugverwijzing door het Hof. Respondenten werd gevraagd te reflecteren op hun eigen rol tijdens de verschillende stadia van de procedure en hoe zij met de uitdagingen die zich daarbij voordeden, waren omgegaan.

Met uitzondering van één interview via online videoconferentie met een respondent in het buitenland en één telefonisch interview, zijn alle interviews in persoon afgenomen. De gemiddelde duur van de interviews was ongeveer anderhalf uur, variërend van veertig minuten tot twee uur en 45 minuten. De interviews werden afgenomen tussen het voorjaar van 2013 en de zomer van 2016, met de meerderheid in 2013 en 2014. De interviews werden opgenomen, woordelijk getranscribeerd en vervolgens geanalyseerd met behulp van kwalitatieve data-analyse software Atlas.ti.

Dit artikel is als volgt opgebouwd. Paragraaf 2 geeft een beknopte verkenning van de sociaalwetenschappelijke literatuur over het belang van vertegenwoordiging in de rechtszaal. Daarna volgt in paragraaf 3 een korte schets van de prejudiciële procedure en enkele feiten over de aard van de respondenten die aan bod komen, alsmede de context waarbinnen zij in deze zaken opereren. In paragraaf 4 worden vervolgens de onderzoeksbevindingen gepresenteerd en geanalyseerd. Paragraaf 5 reflecteert op deze bevindingen en maakt de balans op voor de vraag wat op basis van de gepresenteerde bevindingen kan worden geconcludeerd over de effectiviteit van juridische vertegenwoordiging bij prejudiciële procedures. Paragraaf 6 sluit af met een korte conclusie.

\section{Aspecten van vertegenwoordiging}

Er is veelvuldig onderzoek gedaan naar de rol en noodzaak van advocaten in het bijstaan van partijen. Zo is er binnen sociaalwetenschappelijke bestudering van het recht ruime aandacht voor de effecten van vertegenwoordiging (of met name het gebrek daaraan) in de rechtszaal. ${ }^{4}$ Toegang tot juridische diensten staat centraal in het wetenschappelijk denken over toegang tot het recht. Met name de door Cappaletti en Garth geïdentificeerde 'eerste golf' van onderzoek en hervormingen richtte zich op de uitbreiding van pro bono werk door advocaten en

4 Zie bijvoorbeeld het zogenoemde Florence Access-to-Justice Project, waarin wereldwijde ontwikkelingen op het gebied van toegang tot het recht werden samengebundeld en geanalyseerd. Zie ook Abel 2006, Engler 2006, Hagen 1983, Hammer \& Hartley 1978, Udell \& Diller 2007. 
publiek gefinancierde rechtsbijstand om de toegang van de armere delen van de samenleving tot juridische vertegenwoordiging te vergroten. ${ }^{5}$

Het koppelen van de toegang tot advocaten aan de toegang tot het recht berust op een centrale premisse: de complexiteit van het recht schept barrières voor degenen die er niet in geschoold zijn. Advocaten worden dan ook geïdentificeerd als de zogenoemde 'poortwachters van het recht', in het bijzonder bij formele juridische procedures. ${ }^{6}$ De aanname hierbij is dat wanneer advocaten relevante feiten naar voren brengen en de juiste juridische middelen inzetten - bijvoorbeeld doctrines, moties en juridische argumenten - dit leidt tot resultaten die juridisch gezien juister zijn dan wanneer leken onvertegenwoordigd in de rechtszaal verschijnen. Zonder vertegenwoordiging kunnen partijen wiens rechtszaak een gunstig oordeel verdient toch verliezen, omdat ze niet weten hoe zij de merites van hun claim effectief moeten communiceren binnen de juridische context van de rechtspraktijk.

Het hierbij behorende ideaalbeeld van advocaten is dat zij zijn opgeleid in de voor hun vakgebied relevante rechtspraktijk, kennis hebben van de wet en relevante jurisprudentie gebruiken om iemands belangen te behartigen. De aanwezigheid van deze professionals draagt daarmee bij aan de zogeheten equality of arms van partijen in de rechtszaal. Op basis van dit ideaalbeeld komen we tot de logische conclusie dat de juridische training en kennis die de advocatuur meebrengt van essentieel belang zijn voor effectieve belangenbehartiging. Het heersende inzicht hierbij is dan ook dat advocaten, met hun professionele kennis en expertise een functie vervullen die de niet in het recht geschoolde leek onmogelijk zelf voor zijn rekening kan nemen.

Uitvoerig onderzoek naar de invloed van vertegenwoordiging laat inderdaad zien dat advocaten of andere juridische professionals van wezenlijk belang zijn om de kansen van iedereen die de rechtszaal binnenkomt te verbeteren. ${ }^{7}$ Sociaalwetenschappelijk onderzoek heeft ons echter attent gemaakt op de sociale realiteit die maakt dat het uiteindelijke resultaat van gerechtelijke procedures niet slechts afhangt van de relatieve juridische merites van tegengestelde standpunten. In het kader van ongelijkheden binnen de rechtspraktijk beschreef Galanter de verschillen tussen typen procespartijen. Hij onderscheidde binnen het rechtssysteem de zogenoemde repeat players, met herhaaldelijke proceservaring, van de zogenoemde one shotter, de partijen die slechts een enkele rechtszaak meemaken. ${ }^{8}$ Repeat players hebben door hun herhaaldelijke contact met de rechtspraktijk een streepje voor op partijen die slechts sporadisch met het recht in aanraking komen. De toegang tot specialisten is hierbij een van de voordelen die maakt dat deze repeat players uiteindelijk door de bank genomen beter af zijn.

Advocaten zijn volgens de typologie van Galanter zelf in zekere zin repeat players die, door kennis van zaken én routinematig optreden in de rechtszaal, expertise

7 Zie bijvoorbeeld Chadha 1996, Doran et al. 2003, Hammer \& Hartley 1978, Kritzer 1998, Seron et al. 2001 en Steinberg 2010.

8 Galanter 1974. 
en informele relaties binnen de rechtsinstellingen weten te ontwikkelen. Omdat rechtbanken (althans formeel) leken en door advocaten vertegenwoordigde partijen als gelijkwaardig behandelen, wordt van ervaren partijen verondersteld dat zij, onafhankelijk van de merites van een zaak, een voordeel behalen door hun grotere kennis van de spelregels.

Recent onderzoek van Sandefur, die een meta-analyse deed van onderzoek over de afgelopen decennia in de civiele rechtspraak in de VS, laat dan ook zien dat er ruime verschillen bestaan in het effect van de aan- dan wel afwezigheid van juridische vertegenwoordiging wanneer onderscheid wordt gemaakt tussen verschillende typen zaken, verschillende procedures en verschillende rechtsgebieden. Over de variatie in uitkomsten van verschillende onderzoeken schrijft Sandefur:

'Conclusions from past work are bedeviled by a lack of clear theory about how lawyers might affect case outcomes and by variations in research design. The observational design of most work means that processes of causality and selection drive the findings; and most studies' focus on a single court or kind of case makes it difficult to assess what lawyers are doing in general that may affect how adjudication turns out.' ${ }^{\text {9 }}$

Op zoek naar een antwoord op de vraag waar die verschillen vandaan komen, onderzocht Sandefur welke aspecten van de juridische beroepspraktijk de grootste impact hebben. Zij maakte daarbij een onderscheid tussen inhoudelijke aspecten - de expertise en juridische kennis van advocaten - en de meer relationele aspecten - de ervaring met de beroepspraktijk die advocaten met zich mee brengen. 'Relational expertise', zo stelt Sandefur, 'means understanding the social distribution of knowledge and discretion in the actual relationships through which professional work takes place: knowing, for example, a given judge's patience with rambling explanations'. ${ }^{10}$

Uit de meta-analyse van Sandefur blijkt dat wat statistisch gezien de grootste impact heeft op het verloop van een rechtszaak, en daarmee de gemiddelde succeskansen van partijen, niet zozeer de inhoudelijke juridische kennis van de advocaten is, maar de kennis van de praktijk en van de manier waarop een rechtbank werkt. Zo blijkt niet de inhoudelijke expertise van advocaten, maar de meer relationele expertise de grootste impact te hebben wanneer je de succeskansen van wel en niet vertegenwoordigde partijen tegen elkaar afzet. Sandefur concludeert:

'[L]awyers' impact comes more from managing relatively simple legal procedures than from deploying the complex legal theories or doctrines that are the stuff of formal legal education. Lawyers' impact also reflects their relationship to the court as professionals who understand how to navigate a rarefied interpersonal world. 11 
Op basis van deze bevindingen kunnen we concluderen dat de klassieke lezing, die stelt dat het de professionele kennis en expertise is die maakt dat advocaten onontbeerlijk zijn, niet zonder meer kan worden aangenomen. Minder inhoudelijke eigenschappen, zoals kennis van de procedures en de praktijk binnen specifieke rechtsinstellingen, blijken minstens zo relevant in het vormgeven van de meerwaarde van advocaten in juridische procedures.

De belangwekkende statistisch onderbouwde inzichten over de verschillende vormen van expertise van advocaten roept de vraag op hoe dit in de praktijk uitwerkt. Voor een beter begrip van de wijze waarop dit in de dagelijkse praktijk van de advocatuur vorm krijgt, is het van belang het werk van advocaten in specifieke context te onderzoeken. Door middel van een kwalitatieve benadering van de rechtspraktijk kan inzicht worden verschaft in de wijze waarop de verschillende vormen van expertise die advocaten met zich meebrengen in verschillende context relevant blijken.

Het in de inleiding aangehaalde artikel in A\&MR geeft een indicatie van de uitdagingen waar advocaten mee geconfronteerd worden bij verwijzing naar het Hof in Luxemburg. De specifieke context van de prejudiciële procedure biedt ons aldus een casus waarbij advocaten worden geconfronteerd met een situatie waarbij hun expertise, zowel inhoudelijk als relationeel, niet vanzelfsprekend is. Daarmee biedt deze procedure een uitstekende mogelijkheid om de uitwerking van deze verschillende vormen van expertise in de praktijk nader te onderzoeken. Aangezien het onderzoek beperkt blijft tot advocaten die individuele burgers vertegenwoordigen, blijft de invloed van deze vormen van expertise op procesuitkomsten in de vergelijking met partijen die zichzelf vertegenwoordigen en met advocaten die instellingen, bedrijven of lidstaten vertegenwoordigen buiten beschouwing. Bovendien vervult de procedure binnen het Europese rechtssysteem een cruciale functie en kunnen de uitspraken van het Hof in deze zaken grote gevolgen hebben voor de belangen van hele categorieën personen in geheel Europa, bijvoorbeeld migranten, arbeiders en consumenten. Effectieve vertegenwoordiging, zo kan worden betoogd, wint in een dergelijke context, met verregaande collectieve gevolgen, aan belang.

Door ons te richten op prejudiciële verwijzingen - een belangrijke, maar in alle opzichten zeldzame, procedure - kunnen we bezien hoe advocaten omgaan met een situatie waarin deze verschillende vormen van expertise onder druk staan.

\section{De prejudiciële procedure en advocaten}

In deze paragraaf zal in het kort de prejudiciële procedure worden beschreven en zal een beeld worden geschetst van de respondenten die in dit artikel aan bod komen. De inzichten die in deze bijdrage worden gepresenteerd, zijn zoals gezegd gebaseerd op empirisch onderzoek naar de praktijk van de prejudiciële procedure, en haar belang binnen het Europese rechtssysteem. ${ }^{12}$ Het belang van de procedure die nationale rechters in staat stelt prejudiciële vragen voor te leggen aan het 
Hof van Justitie van de EU in Luxemburg is moeilijk te overschatten. Waar in de literatuur over de relatie tussen recht en politiek in de 'constructie van Europa'13 het Unierecht wordt omschreven als de 'motor' achter Europese integratie, wordt de prejudiciële procedure - de judiciële 'dialoog' tussen het Hof en nationale rechters - gezien als de 'ruggengraat' van het Europese rechtssysteem. ${ }^{14}$

De procedure biedt in de eerste plaats een middel om de rechtszekerheid binnen de EU te waarborgen door een uniforme toepassing van het Unierecht in de verschillende lidstaten. ${ }^{15}$ Hiernaast geniet de procedure onder zowel juristen als politicologen ruime academische aandacht om de transformatieve werking die uitgaat van de jurisprudentie die door het Hof in dergelijke zaken wordt gecreëerd, en de mogelijkheden die dit biedt voor partijen in de strijd om individuele en collectieve belangen. Zodoende wordt de procedure ook wel omschreven als een van de juridische instrumenten die structureel benadeelde groepen en individuen - zoals consumenten, migranten en arbeiders - de mogelijkheid biedt om middels Unierecht op supranationaal niveau rechten af te dwingen. ${ }^{16}$ Effectieve belangenbehartiging is daarbij vanzelfsprekend van groot belang.

In totaal worden elk jaar zo'n vijfhonderd zaken bij het Hof aangebracht middels een prejudiciële procedure. In de praktijk loopt het aantal zaken dat wordt doorverwezen naar het Hof in Luxemburg zeer uiteen, zowel wat betreft verschillende rechtsterreinen als verschillende lidstaten. Traditioneel gezien behoort Nederland tot een van de koplopers waar het gaat om aantallen verwijzingen, zowel in relatieve (aantal zaken per hoofd van de bevolking) als in absolute zin, met jaarlijks gemiddeld zo'n dertig verwijzingen. ${ }^{17}$

Advocaten die hebben gewerkt aan een zaak die het Hof heeft bereikt via een prejudiciële verwijzing, behoren tot een zeer selecte groep. In acht nemende dat rechters in Nederland slechts een dertigtal verwijzingen per jaar doen, is een doorverwijzing naar Luxemburg voor de meeste advocaten een zeldzame ervaring. Voor het overgrote deel van hen zal dit slechts één keer in hun gehele loopbaan voorkomen. Door de bijzondere aard van de prejudiciële procedure en de veelheid van onderwerpen en rechtsterreinen die voor het Hof worden gebracht, kan de groep geïnterviewden dan ook nauwelijks als homogeen worden beschouwd. In veel opzichten delen deze professionals slechts het feit dat zij aan deze procedure hebben deelgenomen. Onder de geïnterviewden bevinden zich zowel advocaten van grotere advocatenkantoren (met name op het gebied van het fiscaal recht) als veel eenmanskantoren.

Advocaten in zaken die naar het Hof worden doorverwezen, zijn over het algemeen genomen geen Unierecht-specialisten. Zij zijn asieladvocaten, socialezekerheidadvocaten, maar ook accountants en belastingadviseurs. Een enkeling (drie van de 28) heeft eerdere ervaring met prejudiciële procedures, maar de

\section{Rosas, Levits \& Bot 2013.}

Vauchez 2008.

Weatherill 2014, p. 86.

Cichowski 2007. Zie ook Hoevenaars 2018.

Nederlandse rechters sturen jaarlijks tussen de twintig en veertig zaken naar het Hof, waarmee Nederland consequent in de top 5 van meest verwijzende EU-lidstaten staat. Statistieken beschikbaar op: http://curia.europa.eu. 
ruime meerderheid had slechts één keer een zaak die naar het Hof werd doorverwezen. Hoewel in de literatuur doorgaans wordt uitgegaan van doelbewuste strategieën achter verwijzingen naar Luxemburg, blijkt uit dit onderzoek in Nederlandse context dat deze zaken zeker niet altijd in Luxemburg terechtkomen, omdat partijen daar in de nationale procedure op aansturen. Sterker nog, een meerderheid van de geïnterviewde advocaten was in het geheel niet voorbereid op een verwijzing. ${ }^{18}$ Zoals hierna zal blijken, zijn deze twee factoren, de onverwachte verwijzing en de onervarenheid van deze advocaten, van grote invloed op de wijze waarop zij hun taak als juridische vertegenwoordiger kunnen vervullen.

In het hiernavolgende zullen de inzichten worden gepresenteerd die middels de interviews met advocaten werden verkregen over de vraag welke uitdagingen advocaten tegenkomen wanneer hun zaak wordt doorverwezen naar het Hof van Justitie en hoe zij hiermee omgaan.

\section{De prejudiciële procedure in de praktijk}

De vraag die in dit artikel centraal staat, is met welke uitdagingen advocaten worden geconfronteerd wanneer een zaak waarbij individuele burgers zijn betrokken wordt doorverwezen naar het Hof van Justitie, hoe zij hiermee omgaan en wat we hieruit kunnen concluderen over de effectiviteit van juridische vertegenwoordiging bij prejudiciële procedures. In het hiernavolgende worden vier thema's besproken die in de interviews met advocaten veelvuldig naar voren kwamen en welke inzicht geven in hoe de onbekendheid met de procedure het werk van de advocaten beïnvloedt.

\subsection{Complexiteit}

De eerste uitdaging voor advocaten bij prejudiciële verwijzingen betreft de verandering in context van de zaak. Deze verandering vindt plaats op twee terreinen. Ten eerste procedureel, waarbij advocaten zich moeten verdiepen in een procedure die nieuw voor hen is, en ten tweede inhoudelijk, in termen van het vraagstuk dat centraal staat in de prejudiciële procedure ten opzichte van de nationale procedure.

De tijd die advocaten aan het referentiegedeelte van een zaak besteden loopt zeer uiteen, variërend van geen extra werk (door de veronderstelling dat het pleidooi in de nationale procedure volstaat) tot een aantal volledige werkweken. In eerste instantie kan de tijdsbesteding al toenemen door het simpele feit dat de procedure anders is dan de procedures in nationale context, waar zij dagelijks mee te maken hebben en waar zij een werkwijze voor hebben ontwikkeld. Nog voor de specifieke inhoudelijke context en daarmee gemoeide juridische werkzaamheden,

18 Deze bevinding is in tegenspraak met uitkomsten van eerder onderzoek naar de achtergrond van dergelijke zaken in Engeland, waarbij werd geconcludeerd dat zaken meestal worden doorverwezen als een van de partijen hierop aanstuurt. Zie Chalmers \& Chaves 2011. Deze tegenstrijdige bevindingen suggereren dat de wijze waarop zaken het Hof bereiken per lidstaat verschilt. Een belangrijke vraag die buiten het bestek van dit artikel valt, is derhalve in hoeverre de gepresenteerde bevindingen zich laten generaliseren naar andere lidstaten. 
moeten advocaten zich verdiepen in de specifieke tijdslijn, procedurele regels en andere voor deze procedure typische vereisten. Een advocaat gespecialiseerd in sociale zekerheid beschrijft de extra tijd die nodig is voor het voldoen aan de procedurele vereisten in een verwijzingszaak:

'Ik ben er heel veel tijd aan kwijt geweest. Of het allemaal echt efficiënt gewerkte uren zijn, weet ik niet. Het opstellen van de stukken, het verzamelen van bijlagen op een zondagmiddag, en het 6 keer kopiëren zodat het op tijd bij de griffie kan zijn. En dan ontdekken dat de formele termijn op maandag is dus shit, ik heb vandaag nog iemand nodig die ervoor zorgt dat het er morgen is. Nou, en dan ben je hier de hele dag. Vroeg in de ochtend naar kantoor en 's avonds om ongeveer acht of negen uur vertrekken. Simpelweg omdat ik het voor de eerste keer doe, het is allemaal nieuw, een nieuw soort stress. Dat kost allemaal gewoon meer tijd.'

Indien deze deel uitmaken van hun netwerk, wenden advocaten zich tot collega's met eerdere ervaring met prejudiciële verwijzingen voor hulp bij deze procedurele aspecten van hun zaak. Echter, met de schaarste aan verwijzingen is de groep ervaringsdeskundigen zeer beperkt. In sommige gevallen leidt dit ertoe dat advocaten besluiten om simpelweg te wachten op de antwoorden door het Hof en geen extra tijd te besteden aan verdere inhoudelijke behandeling van hun zaak. Zoals beschreven door een belastingadviseur van een klein belastingadvieskantoor:

'Dus de volgende vraag was, of we iemand hadden die al had geprocedeerd bij het Europees Hof van Justitie. Dat was niet het geval. En hoe werkt dat? We weten hoe we moeten procederen bij de Hoge Raad in belastingzaken, waar het meestal een schriftelijke procedure is, alleen maar om te zien of de lagere rechtbank de wet correct heeft toegepast. Dus we hadden, niet wetende hoe te reageren, besloten te doen alsof we naar de Hoge Raad gingen. Dus, in die zin om niets te doen en gewoon af te wachten hoe de prejudiciële vragen zouden worden beantwoord.'

Een aantal advocaten verklaarde in eerste instantie eenzelfde inschatting te hebben gemaakt van zowel de aard van de procedure, waarbij niet meer wordt gedaan dan de in de nationale procedure ingebrachte argumenten aan het Hof te zenden, alsook van de noodzaak tot het verder bijwonen van een hoorzitting. Deze inschatting werd gemaakt op basis van de gepercipieerde complexiteit van de vragen die aan het Hof werden voorgelegd en de ingeschatte mogelijkheden die advocaten zagen in het verder beïnvloeden van de uitkomst van een prejudiciële verwijzing.

De complexiteit van een verwijzingszaak wordt echter niet in alle gevallen door betrokkenen juist ingeschat. Zo bleek bovengenoemde belastingzaak uit te monden in een belangwekkende strijd over de houdbaarheid van Nederlands beleid voor de zelfstandigenaftrek voor buitenlandse belastingplichtigen in het licht van EU-regels omtrent vrijheid van vestiging. Deze zaak werd uiteindelijk, door tussenkomst van de Europese Commissie, overgenomen door twee specialisten op 
het terrein van het Europees belastingrecht om de belangen van de cliënt, en daarmee de positie van de Commissie, effectiever te behartigen. ${ }^{19}$

De vertaalslag die advocaten moeten maken in een zaak van een op nationale context gerichte casus, naar de mogelijk bredere impact die een vraagstuk over Unierecht zou kunnen hebben, is voor velen geen eenvoudige stap. Zoals gezegd waren veel advocaten op geen enkele manier experts op het gebied van Unierecht. Slechts 6 van de 28 geïnterviewden verklaarden meer dan een basale kennis te hebben van de jurisprudentie van het Hof die relevant is voor hun rechtsterrein. Bovendien was de expertise die advocaten zeiden te hebben meestal post hoc opgedaan, tijdens het werken aan de zaak die werd doorverwezen naar het Hof. Zoals verklaard door een migratierechtadvocaat:

'Ik heb veel geleerd van dit ene geval en heb het echt geïnternaliseerd. Wat in dit geval echt belangrijk was, was het effect utile. Dat is wat je leert wanneer je op een Europese manier begint te denken, je moet altijd zeggen: als je het zo doet, druist dat in tegen het effect utile.'

Voor het overgrote deel van de advocaten was dus de verwijzing naar het Hof het eerste moment waarop zij zich daadwerkelijk verdiepten in Unierecht. Op de vraag hoe om te gaan met de focus op het Unierecht in plaats van op het nationale recht of de nationale procedure, antwoordt een belastingadviseur dan ook:

'Het is een vrij ingewikkelde vertaalslag. Het wordt een abstractieniveau hoger getild met de rechtsvraag over EU-recht en komt daarmee veel verder van het nationale af te staan. Die stap is niet eenvoudig te maken, het vraagt echt wel even wat tijd om je die stof eigen te maken, voor zover je dat überhaupt lukt.'

Het nationale is uiteraard de context waarbinnen deze advocaten bekend zijn te werken en waar zij zich in hun dagelijkse praktijk mee bezighouden. Advocaten waren zelf vrij duidelijk over de mate waarin hun expertise tekortschoot in het maken van deze vertaalslag. Zo concludeert een asieladvocaat:

'Ik heb wel eens vaker geroepen dat er een cursus "beginselen EU-recht" gegeven moet worden [...] over hoe je het effectiviteitsbeginsel in, bijvoorbeeld de definitierichtlijn toepast, hoe je daarmee kan werken in je praktijk. Volgens mij weet iedereen wel een beetje wat het effectiviteitsbeginsel inhoudt, maar niemand heeft het in zijn vingers om er echt mee te kunnen werken. Zodat je daar dan bij wijze van spreken een college over kunt geven bij de [Nederlandse] rechter. Dat is eigenlijk wat er moet gebeuren, want die rechters snappen het ook niet.' [lacht]

19 Uitgebreidere behandeling van deze specifieke zaak, en de hierbij cruciale rol van de Europese Commissie, is te vinden in Hoevenaars 2018, par. 6.7. 
Nadat de vragen door de nationale rechter aan het Hof zijn voorgelegd, wordt de partijen verzocht hun opmerkingen te maken en hun standpunt te formuleren over hoe in hun ogen de vragen moeten worden beantwoord. De aard van de geformuleerde prejudiciële vragen, waarin een complexe combinatie van nationaal recht, Unierecht, jurisprudentie van het Hof, en de praktijk van beleid relevant kan zijn voor de beantwoording van de vragen, kan een geheel andere aanpak vereisen dan in het hoofdgeding voor de nationale rechter van toepassing was. In dergelijke gevallen komt het voor dat advocaten alleen al in de voorbereiding van het schriftelijke gedeelte van de procedure een aantal volle werkweken aan een zaak besteden. Vooral voor de eenpersoonskantoren, die doorgaans niet beschikken over de nodige personele flexibiliteit, vormt dit een uitdaging. Zoals één sociale-zekerheidadvocaat verklaart:

'Het blijft waanzinnig moeilijk. Maar goed, dat moet je dan wel gewoon doen. Dan moet je een memorie schrijven. Dan moet je je gewoon minimaal een week opsluiten. En voor de zitting moet je je ook goed voorbereiden. Alle lidstaten die reageren, die doen dat allemaal op het laatste moment. Dus dat is een enorm gevecht tegen de tijd, want je krijgt er dan helemaal niet zoveel tijd voor. En dan daarna, heel veel tijd later heb je dan een zitting, dus dan is alles weer weggezakt, dus voordat je dan weer op niveau bent ben je weer zoveel dagen verder.'

\subsection{Tijd, kosten en het inroepen van hulp}

Een verwijzing kan inhoudelijk complexiteit toevoegen die advocaten dwingt om meer tijd aan een zaak te besteden dan ze in veel gevallen hadden verwacht. Het is met name in de sociale advocatuur, waar cliënten geen grote beurs hebben, aan de advocaat om te beslissen of hij of zij bereid is deze extra investering zelf te dragen. Effectieve belangenbehartiging is in deze gevallen dus voor een groot deel afhankelijk van de persoonlijke investering van de betrokken advocaat. Zoals uitgelegd door een advocaat gespecialiseerd in migratierecht:

'Wij hebben een beetje een raar vak in de sociale advocatuur. We krijgen gewoon een vastgesteld bedrag voor een zaak, en het loont eigenlijk niet om je werk té goed te doen. Dat klinkt heel raar, en daarmee wil ik niet zeggen dat ik mijn werk per definitie niet goed doe. Maar weet je, je krijgt 8 uur betaald. En zo'n zaak die kost gewoon al veel meer tijd, maar de kans dat je meer betaald krijgt is gewoon buitengewoon klein. Dus op het moment dat je rond die 20 uur komt te zitten, dan moet je ook na gaan denken, hoe ver duik je er in. En dat betekent dat je soms niet alles eruit kunt halen, omdat het gewoon commercieel niet verantwoord is.'

Het merendeel van de geïnterviewde advocaten gaf aan al in een vroeg stadium te onderkennen dat zij inhoudelijk niet goed waren toegerust voor het behandelen van hun zaak in het gedeelte van de procedure na verwijzing. Meer dan de helft van de geïnterviewde advocaten besloot dan ook om contact op te nemen met experts in academische kringen, zoals deze asieladvocaat: 
'De vragen werden doorverwezen en ik had zoiets van, oh god. Het kan niet waar zijn dat ik nu degene ben die over deze moeilijke kwestie in het hoogste stadium van Europa moet gaan discussiëren. Ik vind het nog steeds echt schokkend. Maar het wordt plotseling heel groot en dat heb je nog nooit eerder gedaan en je weet echt niet precies hoe je verder moet gaan, hoe het daar allemaal werkt. Dus stuurde ik e-mails naar een hele reeks mensen zo van, help me. Want ik weet het niet. En van de ongeveer twintig mensen die ik had benaderd, bleef er uiteindelijk een kleine groep over, een kern van vier, vijf mensen. Mijn voormalige collega, die nu een proefschrift schrijft, schreef een aanzienlijk deel van de inleiding. En ze kon gewoon alle relevante jurisprudentie reciteren, wat echt fantastisch was. Dat is wanneer je het verschil ziet tussen wetenschappers en praktijkmensen zoals ik. Omdat je als advocaat een beetje weet wat de wet is, maar hoe het precies is geformuleerd en waar je het kunt vinden weet je niet. En dat alleen al kost je drie dagen om uit te zoeken.'

Deze reactie op zijn eigen gebrek aan kennis en de hulp van externe experts, benadrukt niet alleen een algemeen gebrek aan expertise onder degenen die geconfronteerd worden met een verwijzing, het laat ook zien waar de expertise te vinden is. Academici zijn een voor de hand liggende keuze voor de meeste advocaten bij het zoeken naar hulp bij het werken aan de complexiteit van Unierechtsvragen. Experts met een goed begrip van specifieke gebieden van Unierecht en met kennis van de relevante jurisprudentie van het Hof worden meestal gevonden onder rechtswetenschappers. Hoewel hun professionele expertise advocaten helpt hun argumenten te formuleren en relevante jurisprudentie op te nemen, is hun kennis van de praktijk van het Hof van Justitie meestal ook gering. Daarmee is de mate van hulp die ze op dit gebied kunnen bieden slechts beperkt. Dus hoewel het gebrek aan professionele expertise gedeeltelijk kan worden gecompenseerd door pro deo specialisten, zien we dat een gebrek aan relationele expertise niet eenvoudig kan worden opgevangen.

Aangezien de meeste cliënten in de bestudeerde zaken financieel niet in staat zijn om specialisten in te huren, komt ook de extra tijd die advocaten er vaak aan besteden voor rekening, en dus overweging, van de advocaat zelf. Tenzij experts, zoals gezegd doorgaans academici, bereid zijn hun diensten te verlenen zonder betaling, is een beroep doen op de expertise van een advocaat gespecialiseerd in Unierecht en ervaren in het pleiten voor het Hof van Justitie dus voor weinigen weggelegd.

In slechts 1 van de 26 bestudeerde zaken bleken partijen in staat om na verwijzing naar het Hof een Unierecht-specialist met ruime ervaring met pleiten voor het Hof in te huren. Deze uitzondering bevestigt in veel opzichten de regel. De genoemde specialist, met 25 jaar ervaring in het procederen voor het Hof, werd ingehuurd door een vereniging die optrad namens een grote groep gepensioneerden die zich verzette tegen een wijziging van het Nederlandse ziektekostenverzekeringsstelsel. De vereniging was erin geslaagd dankzij aanzienlijke financiële bijdragen van hun uitgebreide ledental de bijkomende kosten te dekken. 
Dit is een treffend voorbeeld van wat Galanter heeft beschreven als de 'allocatieeffecten' van expertise van advocaten. In dit geval betekent dit dat advocaten zich kunnen specialiseren en ervaring opdoen met dit type Unierechtszaken, maar dat we kunnen verwachten dat deze advocaten posities innemen namens de meer vermogende partijen. De grotere bedrijven, lidstaten en instituties, ngo's en collectieven zoals belangengroepen, enzovoort zijn dan ook de repeat players in deze context. ${ }^{20}$ De overgrote meerderheid van de (individuele) partijen kan echter niet profiteren van een dergelijk collectief voordeel en is daarom niet in een positie om van advocaat te veranderen of een deskundige in te huren. In de meeste gevallen is het dus aan de doorsnee asieladvocaat, sociale-zekerheidadvocaat en belastingadviseur om een zaak voor het Hof te bepleiten.

\subsection{Onbekende gang van zaken, onbekende rechters}

Een onderdeel van wat Sandefur, maar ook auteurs als McGuire ${ }^{21}$ en Galanter ${ }^{22}$ noemen als de relationele factoren die maken dat advocaten een positieve rol spelen tijdens procedures, is het feit dat zij bekend zijn met de werkwijze van de rechtbanken waar zij vaak werken, maar ook met specifieke rechters en hun opvattingen, voorkeuren en modus operandi tijdens zittingen. Zoals een voormalig rechter van het Hof het stelt:

'[T] he basic rules of advocacy apply as much in pleading before the European Court of Justice as before any court or tribunal [...]: know your court; know your procedure; and know what you are trying to achieve.. ${ }^{23}$

Ik sprak hierover ook een zogenoemde Euro-lawyer, ${ }^{24}$ een in Unierecht gespecialiseerde advocaat met veel ervaring in het procederen voor het Hof van Justitie, en hij bevestigde dit beeld:

'Je moet je rechter kennen en proberen de jurisprudentie van die rechter te gebruiken. Het kan helpen om te voorkomen dat je grote blunders maakt, door bijvoorbeeld kritiek te geven op de jurisprudentie van een bepaalde rechter. Dus je moet je goed voorbereiden. De hoorzitting kan een groot verschil maken. De uitkomst van een zaak is niet het lastige deel, het is de redenering, en de hoorzitting kan hier veel invloed op hebben.'

Het moge duidelijk zijn dat voor een Unierecht-specialist, en zeker een die vaker voor het Hof pleit, dit een meer realistische opdracht is dan voor de gemiddelde advocaat of belastingadviseur die slechts één keer in zijn loopbaan onverwachts met een zaak in Luxemburg terechtkomt. De onervarenheid van deze advocaten begint eenvoudigweg met de algemene onbekendheid met de procedurele gang 
van zaken voor het Hof. Zoals deze advocaat die verklaart nogal teleurgesteld te zijn over de mate van hulp die hij ontving bij het Hof:

'Ik was niet gelukkig met de begeleiding. Niemand kon mij vertellen waar de advocatenkamer was, en ik moest me nog wel voorbereiden. De beste informatie die ik kreeg was van de tolk. Die kwam aangesneld of ik nog een pleitnota had, en of hij die mocht hebben, dan kon hij zich alvast voorbereiden. Maar in de zaal zaten er bijvoorbeeld knopjes voor de vertalers, dat werd niet uitgelegd. Tijdens de zitting kwam ik erachter dat als je dat knopje indrukt, hoor je wat er gezegd wordt in het Nederlands. Nou gelukkig werd er alleen Engels en Frans gesproken, dat versta ik wel. En waar je je jas moest laten? Ik heb hem maar gewoon tegen de muur gelegd.'

Dergelijke praktische zaken zijn illustratief voor de onbekendheid van advocaten met een rechtbank die ze voor het eerst zien. Dit strekt zich uit tot de vraag hoe ze hun zaak inhoudelijk mondeling moeten bepleiten voor een rechtbank waarmee ze niet bekend zijn, zoals een strafrechtadvocaat uitlegt:

R: 'Op een gegeven moment zeiden ze dat deze zaak naar Luxemburg gaat. Toen dacht ik, ik heb daar echt niets te zoeken. Ik bedoel wat moet ik daar doen? Maar toen de zaak werd doorverwezen naar de Grote Kamer, en toen dacht ik, ja, weet je, ik kan nog zestig jaar werken als advocaat, maar de kans dat ik ooit nog voor de Grote Kamer kom te staan is zo verwaarloosbaar, dat ik moet gaan.'

I: 'En u heeft ook gepleit?'

R: 'Ja, natuurlijk. Als je gaat, dan moet je pleiten ... totaal zinloos!' [Lacht]

I: 'Hoe ging dat?'

R: 'Ja, nou ja, “leuk om hier te zijn, ik wil mijn moeder gedag zeggen”, zoiets.' [lachend]

Naast de vraag van de wijze waarop men zich inhoudelijk tot het Hof zal richten, is het dus ook van belang om voorbereid te zijn op de wijze waarop de procedure wordt gevoerd en kan het helpen om op de hoogte te zijn van de voorkeuren van de rechters. Bij de tweede ronde van een hoorzitting, waarin men het woord mag voeren en mag reageren op de argumenten die door andere aanwezige partijen naar voren zijn gebracht, legt voorgenoemde Euro-lawyer uit hoe zijn ervaring heeft geleid tot beter inzicht in de voorkeuren van de rechters:

"Wat ze "antwoord en dupliek" noemen, is een beetje misleidend; het is meer een conclusie. Je hebt de tijd om te reageren op vragen, maar je moet ook tot een conclusie komen. Rechters hebben een hekel aan herhalingen, en ze zullen je afkappen.'

Dat het er in Luxemburg anders aan toe gaat dan wat advocaten gewend zijn, zit hem, naast de meer organisatorische en procedurele aspecten en de inhoudelijk juridische kant van de zaak, ook in de strakke regie van de hoorzitting, waarbij 
naast beperkte tijd voor het pleidooi ook weinig tijd is voor nadenken of overleg. Voor de onervaren advocaat kunnen dergelijke geschreven en ongeschreven regels en voorkeuren van bepaalde rechters leiden tot een frustrerende ervaring. Met name wanneer de gang van zaken wordt afgezet tegen nationale procedures waar er over het algemeen meer tijd is voor interactie tussen de partijen en meer ruimte om een argument te bepleiten. Zo concludeert een asieladvocaat:

'In het algemeen heb ik die hoorzitting als iets heel vreemds ervaren. Je krijgt vijftien minuten de tijd om je pleidooi snel af te ronden en dan moet je in de tweede termijn reageren op die lidstaten. En dan word je door de voorzitter beledigd met de opmerking dat ik mij op de vragen moet concentreren en tot een conclusie moet komen. Maar ja, die lidstaat heeft allerlei onzin gezegd ik wil dat gewoon rechtzetten. Ik was echt verbijsterd. Dus je pakt jezelf zo goed mogelijk op en reageert een beetje, en dan ga je weer zitten. En als niemand wil reageren, dan is de zitting gesloten en dan loop je weer naar buiten. En ik had zoiets van, hè? Was dit het? Wacht ... wat?'

Advocaten proberen het beste uit de gelegenheid te halen, maar zijn over het algemeen niet erg optimistisch over de ruimte die de hoorzitting biedt voor het bepleiten van hun zaak en met name voor het reageren op de opmerkingen van andere partijen, waaronder de wederpartij, de Europese Commissie en andere lidstaten. Zoals verklaard door een sociale-zekerheidadvocaat:

'Nou, je probeert het, maar dat is erg moeilijk. Je hebt vijftien minuten tijd voor je standpunt tijdens de hoorzitting, of voor wat je nodig acht om aan te zetten. Wat dertig bladzijden kostte om te schrijven. Maar je kunt niet reageren op al die zeven lidstaten, die deels hetzelfde zeggen, maar die in nuances zeer verschillende standpunten hebben. Dus je kunt daar naar mijn mening niet goed op reageren.'

Het technisch-juridische karakter van vraagstukken voor het Hof en de beperkte tijd die men krijgt toebedeeld tijdens een hoorzitting leidt onder sommige advocaten zelfs tot de conclusie dat de hoorzitting niet veel uitmaakt voor de uitkomst van een zaak. En zelfs onder ingewijden bestaat het idee dat de hoorzitting niet meer is dan een teken van goede wil van de rechters, waarvan het praktische belang voor het verloop van een zaak slechts als een hulpmiddel voor de schriftelijke procedure wordt gezien. Het idee van zijn relatief verminderd nut kan een rol spelen bij de beslissing van advocaten om de hoorzitting in Luxemburg niet bij te wonen. Zoals een advocaat gespecialiseerd in sociale zekerheid en arbeidsrecht concludeert:

'De hoorzitting, met alle respect voor iedereen die eraan deelneemt, is volgens mij niets meer dan een ritueel. Alle documenten zijn ingediend; de 
mening van de advocaat-generaal is er al. ${ }^{25}$ Je krijgt ook maar twintig minuten. Met een beetje goede wil kun je het verdubbelen tot veertig minuten. Maar het zou heel slecht zijn, en getuigen van slechte kwaliteit als advocaat, als $\mathrm{u}$ in dat korte pleidooi dingen naar voren brengt die niet in de schriftelijke opmerking zijn opgenomen. Dat zou slecht zijn.'

De mondelinge fase van de procedure biedt partijen echter de enige mogelijkheid om te reageren op opmerkingen van zowel de Europese Commissie als de tussenkomende lidstaten. Bij de prejudiciële procedure is er geen sprake van repliek en dupliek, dus alle argumenten van andere partijen zullen tijdens zitting moeten worden geadresseerd.

'Zij hadden hun stuk opgedeeld in laten we zeggen tien stukken of zo, en dat hadden ze gecoördineerd. Want iedere lidstaat krijgt maar twintig minuten spreektijd, of zo. Dus dan gaat eerst één Lidstaat het eerste argument helemaal uitkauwen. En dan de tweede een andere. Een lang verhaal, dus dan hebben ze niet twintig maar tweehonderd minuten. En wij hadden twintig minuten in ons eentje, en de Commissie ook. En dan moet je in twintig minuten op alles reageren, dus dat is heel slim gedaan.'

De hoorzitting biedt ook met name de gelegenheid om 'zuivere feiten of aspecten van het nationale recht' aan te brengen en te verduidelijken. ${ }^{26}$ Zoals Broberg en Fenger beschrijven: '[O]ften the judges or the Advocate General will ask more argumentative questions in order to test the strength of a legal argument. ${ }^{27} \mathrm{De}$ vragen van de advocaat-generaal en de rechters kunnen een belangrijke rol spelen bij de framing van de kwestie en bieden de mogelijkheid tot verduidelijking van de wijze waarop nationaal beleid in de praktijk uitwerkt - details die van groot belang kunnen zijn voor de uitkomst van de zaak.

De rechters van het Hof vertrouwen voor hun begrip van de feitelijke en juridische context van een zaak, naast op het door de verwijzende rechter aangevoerde verslag, voor een aanzienlijk deel op zowel de schriftelijke als mondelinge bijdragen van de partijen en de Europese Commissie. Aanwezigheid bij de hoorzitting biedt aldus de mogelijkheid om bepaalde punten aan te vullen en te verduidelijken en is de enige mogelijkheid om te reageren op de weergave van de feiten door de andere partijen.

Het feit dat het Hof zich baseert op deze pleidooien voor zijn arrest, en dus het belang van het aanwezig zijn bij de hoorzitting om te reageren op vragen van het Hof en opmerkingen van de andere partijen, wordt bevestigd door beschrijvingen van de gang van zaken tijdens de zitting. Bijvoorbeeld door een vertegenwoordiger in een belastingzaak: 
'De AG vroeg toen aan vertegenwoordiger van de Nederlandse regering: "Stel dat deze meneer dit moet doen, kan hij dan de belastingdienst in het Duits opbellen." Waarop de Nederlandse vertegenwoordiger gewoon zegt: "Ja hoor, ja, absoluut, kan gewoon in het Duits, iedereen spreekt Duits." "En hij kan ook zijn aangifte in het Duits invullen?", "Ja hoor dat kan.". [lacht] Dat is dus een voorbeeld van de waarheid een beetje oprekken. Dus vervolgens vroeg de AG: "dan wil ik graag ook nog de mening van de belanghebbende daarover". En mijn collega deed toen het woord. En die zei: "Ik ben nu al meer dan vijftien jaar belastingadviseur en wat hier nu wordt verteld, dat heb ik nog nooit gezien, dat dat kan." En toen zei die AG: "Ja precies, ik heb geen verdere vragen." Dus toen wisten wij al waar zijn conclusie heen zou gaan.'

De keuze om voor het Hof te pleiten, kan dus de moeite waard blijken te zijn. Het hierboven gegeven voorbeeld onderstreept hoe belangrijk het kan zijn om de rechters van het Hof van Justitie de nodige feiten en context voor een zaak te bieden.

\subsection{Nog een vertaalslag}

Bij verwijzing naar het Hof moeten advocaten aldus, naast de complexiteit van het voorbereiden van hun zaak in een juridische taal en context waarmee zij minder bekend zijn, ook uitzoeken hoe de procedure in zijn werk gaat. Ze moeten uitzoeken wat de termijnen zijn, hoe en wat moet worden opgestuurd en op welke wijze, alsook de door advocaten veel genoemde vraag in welke taal de stukken dienen te worden opgesteld. Die laatste is geen vreemde vraag - het Hof is een EUinstelling en daarmee is vertalen een enorm belangrijk onderdeel van de dagelijkse praktijk. Bijna duizend fte en meer dan $45 \%$ van het personeel van het Hof bestaat uit taal- en vertaaldiensten. Waaronder meer dan zeshonderd juristenvertalers die jaarlijks meer dan een miljoen pagina's aan schriftelijke observaties woord-voor-woord vertalen, en meer dan zeventig tolken die alle interacties tijdens hoorzittingen simultaan vertalen in 552 mogelijke talencombinaties.

Taal heeft dus, naast de meer figuurlijke betekenis in termen van de taal van het Unierecht, ook een veel praktischere betekenis wanneer het aankomt op de praktijk van de procedure. Deze vertaling speelt een rol op twee belangrijke punten. Allereerst bij de ingediende stukken. Hoewel de door partijen ingestuurde schriftelijke opmerkingen zorgvuldig worden vertaald door de vertaaldiensten van het Hof, geldt dit niet voor eventuele bijlagen die bij deze opmerkingen worden gevoegd. Met als resultaat dat waar schriftelijke argumenten sterk leunen op de inhoud van een bijlage, bijvoorbeeld een noot of opiniestuk van een autoriteit op het relevante rechtsterrein, de inhoud van deze bijlage niet door de rechters zal worden gelezen. Partijen dienen dus uitgebreid te verwijzen in hun stukken en de feiten en argumenten inhoudelijk in hun eigen pleidooi over te nemen. Een dergelijk onbekend praktisch detail kan uiteraard de effectiviteit van een ingediend pleidooi ondermijnen.

Ten tweede speelt vertaling een zeer belangrijke rol tijdens de hoorzitting, waar advocaten zijn verplicht in hun landstaal te pleiten. Ter plekke worden alle pleidooien, vragen en antwoorden simultaan vertaald door aanwezige tolken, met het 
daaruit voortvloeiende risico van miscommunicatie, vertaalfouten en minder mogelijkheid tot directe interactie tussen rechters en advocaten. Advocaten wordt dan ook gevraagd om langzaam en duidelijk te spreken, en waar mogelijk, de tolken vooraf hun pleidooien te verschaffen.

De simultaanvertaling heeft zijn weerslag op de manier waarop een hoorzitting vorm krijgt en op de interactie tussen rechters en partijen. Zoals Edward beschrijft:

'To the extent that interpretation is necessary, spontaneity is lost since an interpreter, however skilled, can rarely convey 100 per cent of what is said or, often quite as important, the nuances of how it is said. It is also exceedingly difficult for the listener to concentrate for more than a short space of time on an argument presented through an interpreter.'

Dit wordt in de interviews bevestigd. Zo stelt een asieladvocaat:

'Ik had een zitting voor de grote kamer. En ja, de gang van zaken daar blijft een beetje gek. Vooral ook omdat je communiceert via tolken. Dus al die rechters zitten niet naar jou te luisteren maar naar een oortje. En je hebt daar toch een afstand daardoor. En of mijn punten nu echt goed werden vertaald en over kwamen, geen idee.'

\section{De balans opgemaakt}

De hierboven gepresenteerde resultaten laten zien dat advocaten, wanneer hun zaak wordt doorverwezen naar Luxemburg, voor een flinke opgave staan om hun werk effectief te kunnen doen. Wat kunnen we op basis van deze inzichten concluderen over de effectiviteit van juridische vertegenwoordiging bij prejudiciële procedures?

Het algemene gebrek aan ervaring met procederen in Luxemburg vermindert de effectiviteit van advocaten zodra hun zaak voor het Hof is gebracht. Met name in vergelijking met de juridische professionals die de echte repeat players vertegenwoordigen - de vertegenwoordigers van de lidstaten en de Europese Commissie die dagelijks aan prejudiciële zaken werken en een aanzienlijke bekendheid hebben opgebouwd met de modus operandi van het Hof. ${ }^{28}$

De meeste lidstaten hebben gespecialiseerde Unierecht-advocaten in dienst die regelmatig voor het Hof procederen en die zeer goed vertrouwd zijn met de relevante wetgeving en jurisprudentie en met de wijze waarop het Hof te werk gaat. Wanneer we de doorsneeadvocaat die in Luxemburg terechtkomt, afzetten tegen deze Unierecht-specialisten, wordt duidelijk hoezeer zij zich daar in een underdogpositie bevinden.

Dit wil overigens niet zeggen dat zaken die bij het Hof aanhangig worden gemaakt geen kans van slagen hebben. Integendeel, een ruime meerderheid van 
de zaken die in dit onderzoek zijn meegenomen, werd deels of volledig in het voordeel van de betrokken individuele partijen en tegen de overheid beslist. De ongelijkheid in ervaring met pleiten voor het Hof en expertise op het gebied van Unierecht leidt dus niet zonder meer tot verlies. Dit roept de vraag op hoe dit inzicht te verenigen is met de gepresenteerde uitdagingen waar deze advocaten mee geconfronteerd worden.

Het gegeven dat partijen ondanks de gepresenteerde uitdagingen voor advocaten bij het Hof toch succesvol kunnen zijn, suggereert dat deze aspecten van vertegenwoordiging, tenminste in deze specifieke context, niet de doorslaggevende factor zijn. Hiervoor is een drietal mogelijke verklaringen te geven.

Ten eerste is er sprake van een zekere mate van selectiviteit in de verwijzingsprocedure zelf, die maakt dat deze rechtszaken geen aselecte steekproef zijn uit alle mogelijke procedures. Prejudiciële verwijzingen betreffen dan ook vaak gevallen waarbij er twijfel bestaat over of Europeesrechtelijke verplichtingen van lidstaten worden nagekomen, en of rechten die voortvloeien uit primaire of secundaire Europese regelgeving door lidstaten juist worden toegepast. De onzekerheid bij de verwijzende rechter over toepassing van het Unierecht in de nationale context brengt dan ook een zekere 'selectie bias' ${ }^{29}$ met zich mee die regelmatig in het voordeel werkt van de betrokken consumenten, migranten en werknemers, die ruime bescherming genieten van het Unierecht.

Ten tweede blijkt het overgrote deel van de zaken die voor het Hof worden gebracht administratiefrechtelijke vraagstukken te betreffen over de verenigbaarheid van nationale wetgeving en beleid met Unierecht. In de praktijk zorgt dit ervoor dat de Europese Commissie, de zogenoemde guardian of the treaties, vaak een partij is die inhoudelijk aan de zijde van justitiabelen staat. Zodoende kan de Europese Commissie, in deze context ook wel beschouwd als de repeat player par excellence, ${ }^{30}$ een belangrijke bondgenoot blijken, die bovendien de benodigde expertise en ervaring in huis heeft. De Commissie kan dus tijdens de procedure een compenserende rol vervullen voor enig gebrek aan effectieve procesvertegenwoordiging aan de zijde van de justitiabelen. In een enkel geval gaat de Commissie hierin zelfs verder dan slechts het optreden als een amicus curiae en grijpt zij achter de schermen in aan de zijde van de procespartijen. ${ }^{31}$

Ten derde is het lastig om zaken te differentiëren op basis van de mate van professionele en relationele expertise van derden die voorhanden was. De interviews maken duidelijk dat de context van de prejudiciële procedure zeker zijn weerslag heeft op de wijze waarop advocaten hun werk (kunnen) uitvoeren. Advocaten

29 Over de relevantie van deze bias in onderzoek naar de emancipatoire effecten van de prejudiciële procedure en EU-recht voor traditioneel minder bevoorrechte partijen, zie Hoevenaars 2018, par. 3.8 en 3.11. Zie ook Börzel 2006.

30 Börzel (2006, p. 33) constateerde al dat de Europese Commissie tussen 1978 en 1999 95\% van de door het Hof beslechte inbreukprocedures won. In het geval van prejudiciële procedures blijkt de Commissie ook een positief slagingspercentage te hebben. Stone Sweet \& Brunell (2012, p. 211) constateerden dat wanneer de Commissie en de lidstaten tegenover elkaar stonden, het Hof in de ruime meerderheid (70\%) in het voordeel van het door de Commissie ingenomen standpunt oordeelde.

31 Supra noot 20. 
ondernemen echter tegelijkertijd ook stappen om deze uitdagingen het hoofd te bieden. Een significant deel van de advocaten riep, voor in ieder geval het schriftelijke deel van de procedure, de hulp in van Unierecht-specialisten. In deze zaken werden gevolgen van ontbrekende expertise van de advocaten naar alle waarschijnlijkheid in ieder geval gedeeltelijk gecompenseerd door de bijdragen van aangetrokken experts.

Wanneer we teruggaan naar de bevindingen van Sandefur, die concludeerde dat in vergelijking met niet-vertegenwoordigde justitiabelen de toegevoegde waarde van advocaten met name wordt bepaald door hun relationele expertise, dan is een verwijzing naar het Hof voor advocaten problematisch. Het is precies dit deel van hun professionele kwaliteiten dat hiermee wordt ondermijnd. In die zin is het een interessante vraag of het voor een goed voorbereide zogenoemde 'doe-het-zelver', die de tijd heeft genomen om zich in de gangen van het Hof te verdiepen, daadwerkelijk veel problematischer is dan voor de doorsneeadvocaat, die maar moet zien of hij of zij de tijd kan vrijmaken (en vaak ook de kosten kan verantwoorden) om dit deel van een zaak, vaak veel complexer dan de doorsneepraktijk, tot een goed einde te brengen. Hoewel dit niet is onderzocht, lijkt dat niet kan worden verondersteld dat deze vormen van expertise ook tekortschieten bij advocaten die instellingen, bedrijven of lidstaten vertegenwoordigen voor het Hof. Deze procesvertegenwoordigers kunnen immers eerder als repeat players worden bestempeld en zullen naar verwachting beter in staat zijn om specialisten, en daarmee de relevante expertise, aan te trekken.

Bij de dataverzameling werden twee voorbeelden gevonden waarbij partijen pro se optraden en het Hof uiteindelijk in hun voordeel oordeelde. Een derde in persoon procederende partij wist zijn zaak niet te winnen. Illustratief in dit verband is dat de twee succesvolle zaken beide werden aangespannen door personen met enige juridische expertise. De eerste was een juridisch consulent die als ambtenaar werkte en wel had overwogen een advocaat in de arm te nemen, maar de kosten niet kon opbrengen. De tweede betrof een belastingadviseur die besloot om in eigen naam een procedure te starten tegen het toenmalige Nederlandse BTWbeleid. ${ }^{32}$ De laatstgenoemde verklaarde zijn overwegingen:

'Voor een cliënt zal je nooit zo'n procedure starten, omdat dat veel te veel gaat kosten, en het levert ze uiteindelijk persoonlijk niet veel op. Het was voor mij simpelweg een principekwestie.'

Er was in deze gevallen dus geen sprake van leken die onvertegenwoordigd optraden. Sterker nog, in beide gevallen werd er beduidend meer tijd gestoken in de voorbereiding van de zaak dan partijen op basis van hun beschikbare middelen van een advocaat hadden kunnen verwachten. Beide voorbeelden onderstrepen dat het goed voorbereiden van de procedure dermate hoge kosten met zich meebrengt dat het voor veel justitiabelen onbetaalbaar wordt, en dat advocaten de afweging moeten maken tussen effectieve belangenbehartiging en commerciële haalbaarheid. 
Hoewel er op basis van de gepresenteerde data en de gebruikte methodologie geen eenduidige relatie tussen de kwaliteit van procesvertegenwoordiging en de uitkomst van zaken kan worden geconstateerd, wordt duidelijk in welke mate advocaten die individuele burgers vertegenwoordigen in hun werk worden gehinderd door een verwijzing naar Luxemburg. In hoeverre dit een structureel effect heeft in het nadeel van bepaalde partijen is een lastige vraag waar toekomstig onderzoek mogelijk meer duidelijkheid over kan geven. Dergelijk onderzoek vereist echter een structurele analyse van procedures voor het Hof, waarbij wordt gecontroleerd voor andere factoren, zoals de eerdergenoemde rol van de Commissie, die de uitkomst van een zaak beïnvloeden. Met de genoemde selectie bias en het slechts beperkte totaal aantal verwijzingen ${ }^{33}$ is een dergelijke analyse echter zeer moeilijk te realiseren.

\section{Conclusie}

Sandefur beschrijft hoe de relationele expertise van juridische professionals, hun kennis van procedures en de praktijk binnen specifieke rechtsinstellingen, naast hun inhoudelijke kennis en expertise, in belangrijke mate bijdraagt aan hun positieve impact op de uitkomsten van rechtszaken. In dit artikel is gekeken naar de specifieke context van de Europese prejudiciële procedure, waarbij een rechtszaak vanuit de nationale context wordt doorverwezen naar het Hof van Justitie in Luxemburg.

De gepresenteerde analyse van 26 semigestructureerde interviews met advocaten die bij een zaak betrokken zijn geweest waarin zij individuele burgers vertegenwoordigen in het Hof laat zien hoe een prejudiciële verwijzing zowel de professionele als de relationele expertise van juridische professionals ondermijnt. De verandering van nationale naar Europeesrechtelijke context, alsook de nieuwe procedurele aspecten van een prejudiciële verwijzing, stelt advocaten voor nieuwe uitdagingen waar zij vaak slecht voor zijn toegerust. Dat veel advocaten de hulp inroepen van ervaringsdeskundigen in hun netwerk of, zoals vaker het geval, van Unierecht-specialisten in de academische wereld, onderschrijft in hoeverre zij zichzelf niet in staat achten de belangen van cliënten op dit niveau effectief te behartigen.

Deze inzichten bevestigen Sandefurs bevinding dat de voor de rechtspraktijk relevante professionele expertise meer behelst dan slechts inhoudelijke kennis. Naast de inhoudelijke uitdagingen van een verwijzing naar Luxemburg is ook duidelijk dat de verandering van context repercussies heeft voor de door Sandefur aangehaalde relationele expertise - de bekendheid met de praktijk van specifieke procedures, de werkwijze van specifieke rechtbanken en zelfs voorkeuren van specifieke rechters. In het onderzochte geval moeten advocaten pleiten voor een Hof met een voor hen vreemde procedure, met rechters die ze niet kennen en met een nieuwe gang van zaken waar ze doorgaans on-the-spot op moeten reageren. Juist 
deze expertise, die volgens Sandefur de grootste toegevoegde waarde van de aanwezigheid van advocaten behelst, wordt met een verwijzing naar het Hof tenietgedaan.

De bevindingen in dit artikel geven inzicht in de wijze waarop advocaten die voor het Hof verschijnen hun rol als belangenbehartiger van individuele burgers weten te vervullen. Het feit dat dergelijke zaken niet noodzakelijkerwijs in handen vallen van de professionals die het best zijn toegerust om dergelijke geschillen voor het Hof te bepleiten, alsmede de onmogelijkheid voor met name de minderbedeelde partijen om nadere expertise in te huren, wijzen in de richting van een benadeelde positie voor deze groep rechtzoekenden.

Tegelijkertijd lijken de gevolgen hiervan in het geval van prejudiciële verwijzingen echter mee te vallen, aangezien een meerderheid van prejudiciële verwijzingen in hun voordeel werd beslist. De capaciteiten van de advocaten is dan ook niet de enige factor die meeweegt in het beïnvloeden van de uitkomsten van deze zaken. Het inroepen van pro deo hulp van specialisten en de aanwezigheid van de Europese Commissie als mediërende (f)actor kunnen in belangrijke mate bijdragen aan compensatie van ontbrekende expertise aan de zijde van advocaten.

Voorbeelden van goed voorbereide advocaten die tijdens een hoorzitting feitelijke onduidelijkheden of onjuistheden konden adresseren, en het feit dat de Europese Commissie in een enkel geval zorgdraagt voor meer gespecialiseerde vertegenwoordiging aan de kant van partijen, onderstrepen echter dat in specifieke gevallen de aanwezigheid van kwalitatief goede vertegenwoordiging weldegelijk van invloed kan zijn op het verloop van een zaak. De beschreven invloed van de specifieke context van de prejudiciële procedure op het werk van advocaten geeft dan ook te denken over de effectiviteit van vertegenwoordiging van de (collectieve) belangen van minder bedeelde burgers in Europa.

\section{Referenties}

Abel, L.K., 'A Right to Counsel in Civil Cases: Lessons from Gideon v. Wainwright', Clearinghouse Review 2006-40(2), p. 271-280.

Börzel, T.A., 'Participation through law enforcement: the case of the European Union', Comparative Political Studies 2006-39(1), p. 128-152.

Broberg, M. \& N. Fenger, Preliminary References to the European Court of Justice, Oxford: Oxford University Press 2010.

Cappelletti, M. \& B. Garth, Access to Justice Vol. I: A world survey, Milaan/Alphen aan den Rijn: Giuffrè Editore/Sijthoff/Noordhoff 1978.

Chadha, L.P., Time to Move: The Denial of Tenants' Rights in Chicago's Eviction Court, Chicago: Lawyers' Committee for Better Housing 1996.

Chalmers, D. \& M. Chaves, 'The Reference Points of EU Judicial Politics', Journal of European Public Policy 2011-19(1), p. 25-42.

Cichowski, R.A., The European Court and Civil Society: Litigation, Mobilization and Governance, Cambridge: Cambridge University Press 2007.

Doran, K., J. Guzzardo, K. Hill, N. Kitterlin, W. Li \& R. Liebl, No Time for Justice: A Study of Chicago's Eviction Court, Lawyers' Committee for Better Housing, Chicago-Kent School of Law, Illinois Institute of Technology 2003. 
Edward, D., 'How the Court of Justice Works', European Law Review 1995-20(1), p. 539-558.

Edward, D., 'Advocacy before the Court of Justice: Hints for the uninitiated', in: G. Barling \& M. Brealey (eds.) Practitioners Handbook of EC Law, London: Trenton Publishing 1998, p. 22-45.

Engler, R., 'Toward a Context-Based Civil Right to Counsel through Access to Justice Initiatives', Clearinghouse Rev. 2006-40(2), p. 196-209.

Flyvbjerg, B. 'Five Misunderstandings About Case-Study Research', Qualitative Inquiry 2006(12), p. 219-245.

Galanter, M., 'Why the haves come out ahead: Speculations on the limits of legal change', Law \& Society Review 1974-9(1), p. 95-160.

Galanter, M., 'The Duty not to Deliver Legal Service', University of Miami Law Review 1976-30(4), p. 929-951.

Geertsema, K. \& L. Hesselink 2019, 'Procederen bij het Hof van Justitie EU - "Alles is er helemaal anders"', Asiel \& Migrantenrecht 2019-10(4), p. 162-166.

Granger, M.P., 'States as successful litigants before the European Court of Justice: lessons from the "Repeat-Players" of European litigation', Croatian Yearbook of European Law 2006(2), p. 27-50.

Hagen, J.L., 'Justice for the Welfare Recipient: Another Look at Welfare Fair Hearings', Social Service Review 1983-57(2), p. 177-195.

Hammer, R.P. \& J.M. Hartley, 'Procedural Due Process and the Welfare Recipient: A Statistical Study of AFDC Fair Hearings in Wisconsin', Wisconsin Law Review 1978, p. 145-251.

Hoevenaars, J., A People's Court? A bottom-up approach to litigation before the European Court of Justice, The Hague: Eleven International Publishing 2018.

Kritzer, H.M., Lawyers and Nonlawyers at Work, Ann Arbor: University of Michigan Press 1998.

McGuire, K.T., 'Repeat Players in the Supreme Court: The Role of Experienced Lawyers in Litigation Success', The Journal of Politics 1995-57(1), p. 187-196.

Rosas, A., E. Levits \& Y. Bot, The Court of Justice and the Construction of Europe: Analyses and Perspectives on Sixty Years of Case-law, The Hague: T.M.C. Asser Press 2012.

Sandefur, R.L., 'Access to civil justice and race, class, and gender inequality', Annu. Rev. Sociol. 2008-34(August), p. 339-358.

Sandefur, R.L., 'Elements of professional expertise: Understanding relational and substantive expertise through lawyers' impact', American Sociological Review 2015-80(5), p. 909-933.

Seron, C., G. van Ryzin, M. Frankel \& J. Kovath, 'The Impact of Legal Counsel on Outcomes for Poor Tenants in New York City's Housing Court: Results of a Randomized Experiment', Law and Society Review 2001-35(2), p. 419-434.

Steinberg, J.K., 'In Pursuit of Justice: Case Outcomes and the Delivery of Unbundled Legal Services', Georgetown Journal on Poverty Law and Policy 2010-18(3), p. 453-505.

Stone Sweet, A. \& T. Brunell, 'The European Court of Justice, State Noncompliance, and the Politics of Override', American Political Science Review 2012-106(1), p. 204-213.

Sykes, G.M., 'Legal Needs of the Poor in the City of Denver', Law and Society Review 1969-4(2), p. 255-278.

Udell, D. \& R. Diller, Access to Justice: Opening the Courthouse Door, New York: Brennan Center for Justice at New York University School of Law 2007.

Vauchez, A., "Integration-Through-Law": Contribution to a Socio-History of EU Political Commonsense', EUI Working Paper No. 2008/10, Florence: EUI 2008. 
Vauchez, A., Brokering Europe: Euro-Lawyers and the Making of a Transnational Polity, Cambridge: Cambridge University Press 2015.

Vaughan, D. \& M. Gray, 'Litigating in Luxembourg', Jersey \& Guernsey Law Review 2007(11), p. 1-14.

Weatherill, S., Cases \& Materials on EU Law (11th ed.), Oxford: Oxford University Press 2014. 